\title{
Nas brumas do HGPE: a imagem partidária nas campanhas presidenciais brasileiras (1989 a 2010)
}

\begin{tabular}{c}
\hline \hline Marcia Ribeiro Dias \\
Departamento de Ciências Sociais \\
Pontifícia Universidade Católica \\
do Rio Grande do Sul \\
\hline \hline
\end{tabular}

\begin{abstract}
Resumo: Este artigo tem como ponto de partida a análise de alguns dados coletados em estudos anteriores acerca da imagem partidária construída pelos partidos políticos brasileiros em campanhas eleitorais, incorporando dados e informações relativos às eleições presidenciais de 2010. Entretanto, não se trata de apenas adicionar novos dados a uma estrutura de análise prévia. 0 objetivo é construir um diagnóstico da imagem partidária que vem sendo projetada em campanhas presidenciais no Brasil, entre 1989 e 2010. A discussão dos dados quantitativos é seguida por uma análise qualitativa direcionada especificamente à campanha de 2010. O objetivo é analisar os aspectos mais relevantes do papel dos partidos políticos nas campanhas dos dois principais candidatos em disputa: Dilma Rousseff (PT) e José Serra (PSDB). A discussão sobre o papel do PSDB na candidatura de José Serra centrou-se no discurso antipartidário empreendido pela campanha televisiva. A discussão sobre o papel do PT na candidatura de Dilma Rousseff centrou-se na participação do Presidente Lula em sua campanha na televisão, analisando o papel da liderança na dinâmica eleitoral contemporânea.
\end{abstract}

Palavras-chave: imagem partidária; campanha eleitoral; partidos políticos; eleições presidenciais

Abstract: This article has as its starting point the analysis of some data collected in previous studies about the partisan image built by Brazilian political parties in electoral campaigns, adding data and information from the 2010 presidential elections. However, it is not only adding new data to a prior analysis. The goal is to build a diagnosis of partisan image which has been projected in presidential campaigns in Brazil, between 1989 and 2010. The discussion of the quantitative data is followed by a qualitative analysis related specifically to the 2010 campaign. The objective is to analyze the most relevant aspects of the role of political parties in the campaigns of the two leading candidates in contention: Dilma Rousseff (PT) and Jose Serra (PSDB). The discussion on the role of the PSDB in the candidacy of Jose Serra has focused on anti-party discourse undertaken by his television campaign. The discussion on the role of PT in the candidacy of Dilma Rousseff has focused at the President Lula's participation in her campaign on television, analyzing the role of leadership in contemporary electoral dynamics.

Keywords: partisan image; electoral campaign; political parties; presidential elections 
DIAS, M.R. Nas brumas do HGPE: a imagem partidária nas campanhas presidenciais...

\section{Introdução ${ }^{1}$}

O Horário Gratuito de Propaganda Eleitoral (HGPE), por muitos definido como um "entulho autoritário", uma ingerência arbitrária sobre o legítimo direito de escolha da programação pelo telespectador, é uma das principais fontes de comunicação política na democracia eleitoral brasileira. A propaganda eleitoral na televisão, apesar de definida como obrigatória por seus críticos, em especial as redes de televisão, possui uma audiência voluntária muito maior do que se poderia imaginar². Em 2006, a média de audiência durante o primeiro turno das eleições, segundo o IBOPE, foi de 55,9 pontos, aumentando para 63,2 pontos no segundo turno. Os índices seriam similares aos maiores sucessos da programação televisiva no Brasil. Os dados do Datafolha para 2010 confirmam a alta audiência do HGPE: no primeiro turno, em média, $53 \%$ dos entrevistados afirmaram terem assistido à campanha na televisão, mesmo que eventualmente, enquanto no segundo turno essa média subiu para $60 \%$.

Fonte privilegiada de informações acerca das candidaturas disponíveis, programas de governo e candidatos, o HGPE, por tradição, já faz parte da cultura política e dinâmica eleitoral brasileiras. Por esta razão, justifica-se o estudo do seu conteúdo a fim de apreender o tipo de mensagem que as elites políticas procuram transmitir ao eleitorado e que, acreditam, seja mais eficaz na conquista de votos.

Tal afirmação não ignora que existem estudos importantes que demonstram ceticismo com relação à sua capacidade em pautar os meios de comunicação e interferir de modo significativo na agenda da campanha ou alterar os enquadramentos midiáticos (MIGUEL, 2004). Tal literatura apoia-se na teoria do agenda-setting, através da qual McCombs e Shaw (1972) afirmam a preponderância da agenda da mídia na configuração da agenda pública. Se, entre 1989 e 2002, Miguel (2004) diagnosticou um maior fechamento do telejornalismo às tentativas do HGPE em pautar os noticiários e, segundo ele, revestir-se da legitimidade do discurso midiático, não é possível afirmar seu insucesso na conformação da opinião política que leva à decisão do voto. As campanhas presidenciais de 2006 e 2010 evidenciaram o declínio do poder do discurso midiático sobre a conformação da agenda pública. A reeleição do presidente Lula em 2006 contra uma pauta midiática ostensivamente contrária ao governo federal e apoiada em escândalos de corrupção relacionados a este governo demonstra que a agenda pública não pode mais ser considerada subsidiária da agenda midiática. É possível supor que, entre 1994 e 2002, havia uma convergência entre as agendas do governo e da mídia em geral, o que teria levado, equivocadamente, a crer na supremacia midiática na conformação da agenda pública. Uma vez superada essa convergência durante as eleições de 2006 e 2010, o poder de agendamento da pauta pública pelos meios de comunicação já pode ser questionado³. Existe uma significativa produção acadêmica sobre a propaganda eleitoral na televisão brasileira, o que atesta sua relevância na dinâmica política contemporânea. A grande maioria dos estudos dedica-se à investigação de eleições majoritárias, especialmente as campanhas presidenciais. O primeiro registro significativo ocorreu no final dos anos

\footnotetext{
${ }^{1}$ Este artigo é resultado da pesquisa de Pós-Doutorado realizada na Universidade de Oxford entre agosto de 2010 e julho de 2011, com financiamento da CAPES através do Programa de Bolsas no Exterior - Estágio Sênior. A versão em inglês deste artigo encontra-se publicada na página do Brazilian Program Studies da Universidade de Oxford: http://www.brazil.ox.ac.uk/ data/assets/pdf_file/0005/37940/BSP_paper_Marcia_Ribeiro_Dias.pdf.

${ }^{2} \mathrm{~A}$ audiência é voluntária na medida em que é facultado ao telespectador o direito de desligar o aparelho de televisão e fazer qualquer outra coisa. O HGPE é obrigatório apenas para os canais de televisão aberta, que são concessões do Estado brasileiro.

${ }^{3}$ Sugiro o tema como agenda de pesquisa futura a fim de transformar tal suposição em hipótese de investigação. A base para este diagnóstico, até o presente momento, ainda é impressionista.
} 
1990 com a publicação da tese de Doutorado de Afonso de Albuquerque sobre a propaganda eleitoral na televisão para a eleição presidencial de 1989, a primeira após o fim da ditadura militar (ALBUQUERQUE, 1999). É possível dizer que o autor forjou as primeiras categorias de análise para programas do HGPE, incluindo a referida sigla. Apesar de algumas delas serem circunstanciais, em virtude das especificidades daquela primeira eleição presidencial, muitas de suas categorias analíticas são úteis e ainda apropriadas em estudos recentes. Do ponto de vista metodológico, o artigo de Figueiredo et al (2000) tornou-se referência obrigatória para o estudo das estratégias eleitorais na propaganda política, abrindo um vasto campo de investigações no Brasil.

Depois destes estudos pioneiros, outros se dedicaram a investigar a propaganda eleitoral nas campanhas presidenciais de 1994 (AlbuQUerQue, 1995), de 1998 (VEIGA, 2001; LoURENÇO, 2001), de 2002 (FIGUeIREDO \& CoutinHo, 2003; LouRenço, 2009), 2006 (Dias, 2012) e 2010 (CERVI, MASSUChIm \& TAVARES, 2012), apenas para citar alguns. São estudos que, por diferentes enfoques, discutem o HGPE como instrumento relevante de campanha, na medida em que contribuem significativamente para a construção da imagem das candidaturas e influenciam a decisão do voto.

Ainda incipientes, as análises sobre a propaganda na televisão em eleições proporcionais trazem contribuições importantes, especialmente no que se refere ao papel dos partidos nos processos eleitorais. O artigo de Schmitt, Carneiro e Kuschnir (1999) foi o pioneiro neste tipo de análise e propôs uma metodologia, posteriormente discutida por Albuquerque e Dias (2002b), retomada e aprofundada em Albuquerque, Steibel e Carneiro (2008). Mais recentemente, Cervi (2011) recolocou o assunto em pauta, apresentando o HGPE como recurso partidário de comunicação política em eleições proporcionais.

Neste campo de estudos, meu objeto de pesquisa tem sido analisar o papel dos partidos políticos na propaganda eleitoral na televisão. Qual seria a relevância da instituição partidária na diagramação da campanha televisiva? Em outras palavras, qual seria o peso do partido político na construção da argumentação da campanha? Qual seria sua visibilidade na campanha e a qualidade dessa visibilidade?

Pelas regras gerais de concessão do espaço televisivo às candidaturas, os partidos deveriam ser considerados protagonistas de suas campanhas, uma vez que o tempo para a propaganda política é destinado gratuitamente a eles, proporcionalmente às dimensões de suas bancadas parlamentares federal, estadual e municipal. O HGPE é transmitido ao eleitor-telespectador em blocos veiculados à parte da programação normal durante os dois meses que precedem a data da eleição, e sua duração é estendida em caso de segundo turno para os cargos executivos (Prefeito, Governador e Presidente).

Tais aspectos da legislação eleitoral brasileira poderiam resultar em campanhas intensamente partidárias, devido ao poder comunicativo que é dado a seus agentes. Entretanto, a fragilidade do sistema partidário brasileiro e o personalismo associado a cargos executivos favorecem a elaboração de campanhas eleitorais predominantemente personalistas, contendo algumas vezes discursos antipartidários.

O estudo da propaganda política veiculada no Brasil exige, assim, uma análise dos sistemas eleitoral e partidário, tendo em vista o modo como se conciliam exigências contraditórias de caráter 
DIAS, M.R. Nas brumas do HGPE: a imagem partidária nas campanhas presidenciais...

coletivista e individualista durante a campanha eleitoral ${ }^{4}$. Se, por um lado, o sistema eleitoral brasileiro, "centrado no candidato" (SAMUELS, 1997), fornece um forte estímulo para as estratégias individualistas de campanha, por outro, o modelo vigente de propaganda política na televisão obriga a que os interesses individuais dos candidatos subordinem-se às estratégias coletivas dos partidos. Assim, é possível que o formato de propaganda política na televisão funcione como um instrumento de reforço ao papel que os partidos desempenham no processo eleitoral.

Este artigo incorpora informações relativas à campanha de 2010 a dados coletados em estudos anteriores. Entretanto, não se trata de apenas adicionar novos dados a uma estrutura de análise prévia. Mais do que discutir a presença dos partidos na propaganda eleitoral brasileira, pretendo demonstrar que a polarização entre PT e PSDB que se constituiu no país nos últimos anos não é apenas entre projetos políticos, mas é também entre os papéis dos partidos como instituições democráticas.

A campanha de 2010 foi exemplar neste sentido, uma vez que contrapôs discursos políticos antagônicos. De um lado, encontramos a ideia de continuidade de um projeto que, por ser compartilhado por um grupo político, poderia ter a titularidade transferida de um indivíduo ao outro (de Lula à Dilma) sem o risco de ocorrerem mudanças substantivas. Do outro lado, um projeto baseado na habilidade individual, na capacidade intelectual e política do candidato, ao ponto de atribuir a este candidato os resultados positivos de um governo cuja titularidade não the pertencia, sem ao menos mencionar o Presidente à época (Serra e FHC).

No primeiro caso, a ideia de "partido" é essencial para que o argumento seja convincente; no segundo, a ideia de partido é negada, tratada como um "mal em si", e substituída pelo ideário de união nacional, capitaneada por um líder cuja força moral, capacidade intelectual e habilidade política, demonstradas em sua trajetória de vida, seriam suficientes para a solução dos problemas do Brasil.

Meu argumento é que o PSDB consagrou na campanha de 2010 um discurso anti-partido que já vinha desenvolvendo em campanhas anteriores. A ideia seria minar a força de seu adversário pelo que Ihe fortalece, organização e disciplina partidárias, reforçando um sentimento antipartidário no eleitorado. Tal sentimento teria origem em uma história política de incipiente tradição democrática, cultivado em uma estrutura sócio-política autoritária e em um sistema partidário altamente fragmentado e de frágil enraizamento social.

Neste artigo, discuto os resultados de alguns estudos sobre as peças de campanha elaboradas pelos partidos brasileiros nos últimos anos. O primeiro conjunto de dados (Gráfico 1 ) faz parte de um estudo ainda inconcluso, que leva em consideração campanhas para cargos executivos e legislativos. Os demais gráficos referem-se exclusivamente às campanhas presidenciais, ocorridas entre 1989 e 2010.

A discussão dos dados quantitativos é seguida por uma análise qualitativa direcionada especificamente à campanha presidencial de 2010. O objetivo é analisar os aspectos mais relevantes do papel dos partidos políticos nas campanhas dos dois principais candidatos em disputa: Dilma Rousseff (PT) e José Serra (PSDB). A discussão sobre o papel do PSDB na candidatura de José Serra centrou-se no discurso antipartidário empreendido pela campanha televisiva. A discussão sobre o papel do PT na candidatura de Dilma Rousseff, curiosamente, centrou-se na participação do Presidente Lula em sua campanha na televisão, sem, entretanto, deixar de fazer algumas considerações adicionais.

\footnotetext{
${ }^{4}$ Acerca das instituições representativas no Brasil e seu funcionamento, ver: Kingstone \& Power (2008) e Nicolau \& Power
} (2007). 


\section{Imagem Partidária em Campanhas para Cargos Executivos e Legislativos}

O Gráfico 1 demonstra um panorama geral da participação dos partidos em suas campanhas para diferentes cargos, executivos e legislativos nacionais e locais, a fim de verificar a variação na dimensão ocupada pelos mesmos e discutir as possíveis razões para o fenômeno.

\section{Gráfico 1}

Indicador de Projeção da Imagem Partidária 2004 a 2008

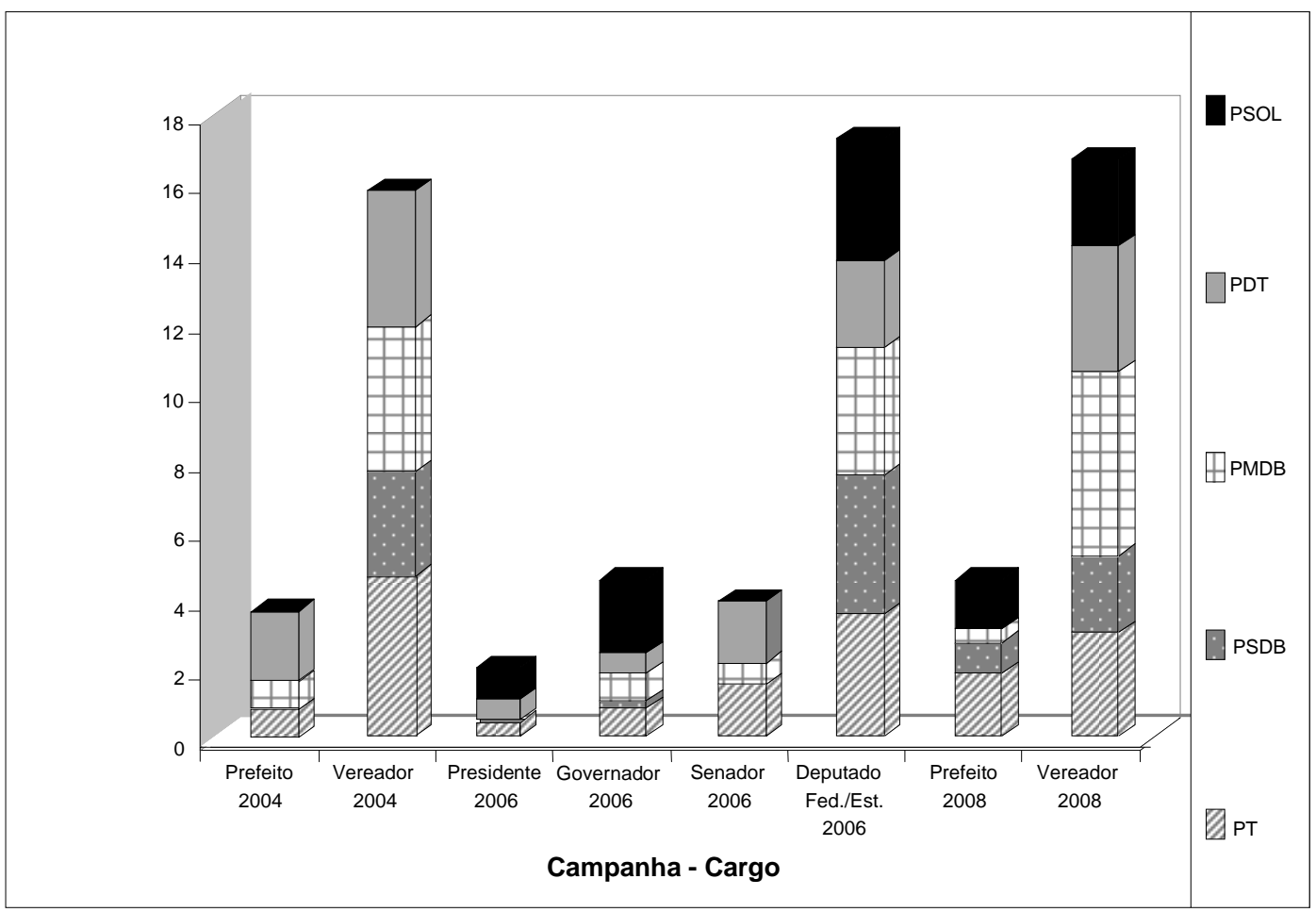

Fonte: Núcleo de Estudos Sobre Poder Partidos e Eleições (NEPPE) do Centro Brasileiro de Pesquisas em Democracia (CBPD) - PUCRS

O primeiro dado que se destaca é a discrepância entre as campanhas majoritárias e proporcionais, de todos os partidos, no uso dos signos partidários. O uso de estratégias partidárias chega a ser cinco vezes maior em campanhas legislativas do que em campanhas majoritárias ocorridas no mesmo ano e empreendidas por um mesmo partido. O que provocaria tal fenômeno? A resposta pode estar nas características do sistema eleitoral que conjuga distintas fórmulas, para distintos cargos, a fim de distribuir cadeiras.

As eleições para cargos executivos no Brasil são majoritárias e centradas na imagem do candidato. Como a identificação partidária no Brasil apresenta níveis pouco significativos para a maioria dos partidos, a determinação do voto pouco se atribui ao partido do candidato. Embora a dimensão ideológico-partidária não possa ser descartada, uma vez que estrutura a disputa eleitoral, no caso brasileiro, os eleitores, geralmente, não se filiam aos partidos políticos de modo definitivo; o que se vê é 
DIAS, M.R. Nas brumas do HGPE: a imagem partidária nas campanhas presidenciais...

muito mais uma opção por determinado campo ideológico, cujo representante partidário irá variar a cada eleição ${ }^{5}$. Assim, as candidaturas para cargos executivos pouco investem na dimensão partidária em suas propagandas eleitorais.

Entre as campanhas majoritárias, a presidencial destaca-se pela quase ausência de marcas partidárias, levando-nos a crer que, quanto mais local é o cargo em disputa, maior será a dimensão partidária na propaganda eleitoral. Neste caso, porém, deve-se levar em conta o fato de que a responsabilidade pela elaboração da propaganda televisiva é dos diretórios partidários: a propaganda presidencial é elaborada pelos diretórios partidários nacionais que, em geral, contratam serviços profissionais para auxiliá.los. As campanhas regionais tendem a ser mais artesanais e, dependendo dos recursos partidários, elaboradas pela própria burocracia partidária.

Os estudos sobre a profissionalização das campanhas eleitorais frequentemente associam esse fenômeno ao declínio da importância dos partidos. A profissionalização das campanhas implica na participação de agentes não-partidários na sua formulação e execução, alijando do processo a tradicional burocracia partidária não-especializada em comunicação política. Assim, quanto mais profissional a campanha, menor importância será dada a critérios político-partidários em benefício de outros relativos ao marketing de produtos comerciais ${ }^{6}$.

Os dados apresentados no Gráfico 1 mostram que a presença de signos partidários é muito mais evidente nas campanhas para cargos legislativos, como se verifica nas colunas relativas às campanhas para vereador em 2004 e em 2008 e deputados em 2006. Atribuímos a explicação novamente ao sistema eleitoral, como determinante do comportamento partidário na elaboração de suas propagandas televisivas. O método eleitoral para a eleição de cargos legislativos é o da proporcionalidade. Assim, uma vez determinado o coeficiente eleitoral, que corresponde ao número de votos necessários para a eleição de cada cadeira, o número de cadeiras obtido por cada partido será determinado pela soma total de seus votos, seja os que foram dados aos candidatos individualmente, seja à legenda do partido. Determinado o número de cadeiras do partido (ou coligação de partidos), estas serão distribuídas aos seus candidatos mais votados. Assim, interessa ao partido, simultaneamente, estimular o voto de legenda e promover candidaturas populares, os puxadores de votos.

Um outro fenômeno contribui para o Indicador de Projeção da Imagem Partidária (IPIP) mais alto em campanhas eleitorais aos cargos legislativos: a promoção da candidatura ao cargo executivo correspondente. $\mathrm{O}$ uso do espaço da campanha legislativa pela campanha majoritária é considerado uma estratégia coletivista e, portanto, partidária, uma vez que interessa ao partido eleger o Prefeito, Governador ou Presidente, e, ao mesmo tempo, garantir-Ihes uma base de apoio no legislativo.

\section{As campanhas presidenciais de 1989 a 2006}

As campanhas presidenciais são as mais profissionalizadas. Os partidos, geralmente, contratam os serviços especializados de alguma agência de publicidade e o que varia entre eles é o grau de controle ou influência que conseguem ter sobre os processos de elaboração da propaganda eleitoral

\footnotetext{
${ }^{5}$ Essa discussão é objeto de pesquisa em desenvolvimento paralelamente, acerca do discurso político nas campanhas televisivas. Ver a respeito Dias (2012).

6 Ver a respeito: Plasser (2001); Gibson e Römmele (2001); Negrine e Lilleker (2002); Römmele (2003); Dias, (2005); apenas para citar alguns.
} 
na televisão. A capacidade de influência dos partidos sobre a propaganda está identificada nos Gráficos 2 a 6, a partir da propagação de suas imagens. Apenas dois partidos participaram de todas as eleições desde a retomada do voto direto para a Presidência da República: o PT e o PSDB, que são o centro desta análise. Outros dois partidos, que participaram de três das seis eleições ocorridas no período, também foram analisados: o PDT e o PPS.

Gráfico 2

Evolução da Imagem Partidária na

Campanha Presidencial (1989 a 2010)

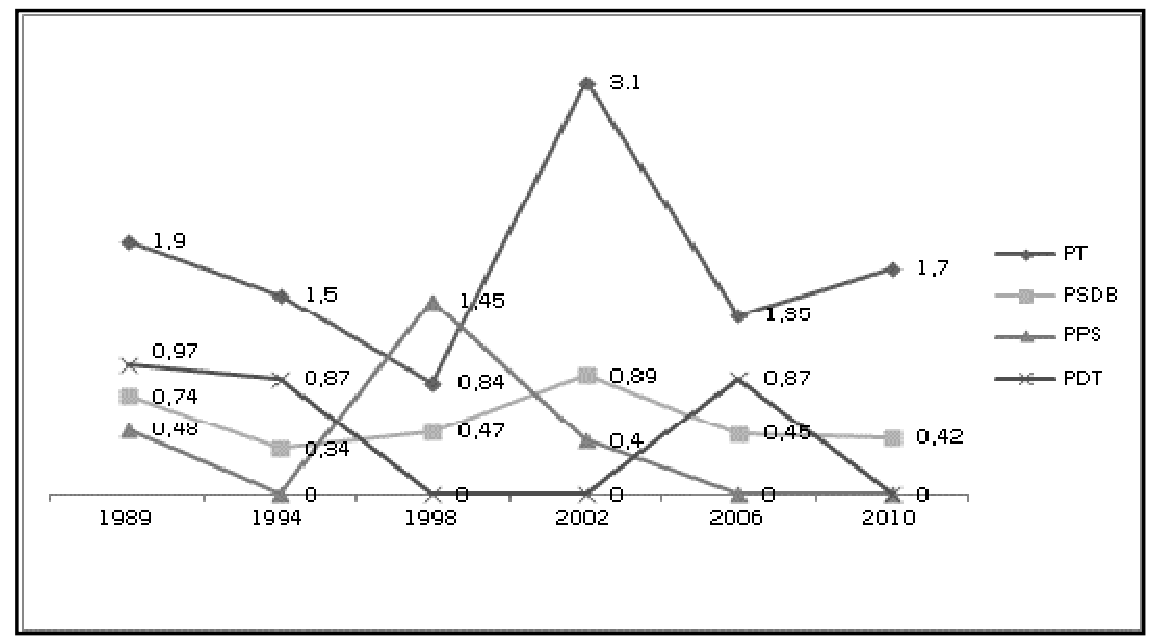

Fonte: Núcleo de Estudos Sobre Poder Partidos e Eleições (NEPPE) do Centro Brasileiro de Pesquisas em Democracia (CBPD) - PUCRS.

De acordo com o Gráfico 2, o PT destaca-se no uso da imagem partidária em seus programas televisivos, especialmente em comparação com outros partidos. Entre 1989 e 2002, todos os partidos analisados reduziram o espaço destinado à projeção de suas imagens, indício da progressiva profissionalização das campanhas presidenciais. A campanha de 1998 foi a menos partidarizada do período, provavelmente em virtude da forte influência que a estabilidade econômica exerceu na dinâmica eleitoral. O temor dos eleitores pela perda do controle inflacionário gerou uma homogeneidade discursiva entre as candidaturas. A campanha de 2002, por ser uma "changing election", ou seja, um contexto no qual se verificou um desejo generalizado de mudança no eleitorado, reforçou a imagem dos partidos concorrentes. Foi neste ano que o PSDB atingiu seu maior Indicador de Projeção da Imagem Partidária, entretanto, ficando ainda abaixo de 1, número mínimo para considerar o partido um ator relevante na propaganda. Em 2006, a imagem do PT sofreu expressiva redução na campanha, atingindo seu menor valor no período, provavelmente, em virtude dos escândalos de corrupção envolvendo importantes dirigentes partidários no ano precedente. A campanha mais personalista do PT centrou-se na imagem do Presidente Lula como fiador do sucesso governamental. Em 2010, registrou-se nova ascensão na imagem partidária do PT e a manutenção, com ligeira queda, do Indicador de Projeção da Imagem Partidária do PSDB. O revigoramento do IPIP do PT e o discurso antipartidário do PSDB em 2010 são objetos de análise posterior. 
Projeção da Imagem Partidária (Média do Período 1989 - 2010)

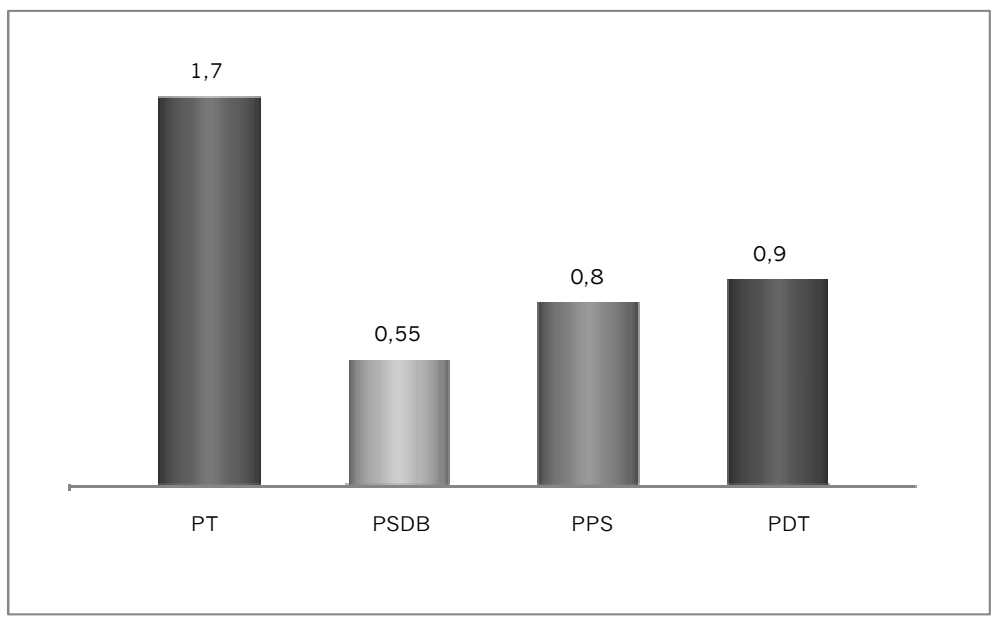

Fonte: Núcleo de Estudos Sobre Poder Partidos e Eleições (NEPPE) do Centro Brasileiro de Pesquisas em Democracia (CBPD) - PUCRS.

Se analisarmos a média do período (Gráfico 3), observamos que as marcas partidárias podem ser identificadas significativamente apenas na propaganda eleitoral do PT, o único partido que pode ser considerado protagonista de sua campanha. O PDT e o PPS participaram com candidatos próprios em apenas três das seis campanhas ocorridas entre 1989 e 2010. Ambos atuaram como coadjuvantes em suas propagandas eleitorais, sendo que o PDT apresentou um comportamento mais homogêneo quanto à projeção de sua imagem. O PPS apresentou uma imagem de mero figurante em duas das campanhas que participou; apenas em 1998 registrou-se um maior empenho na projeção de sua imagem, atingindo o papel de semi-protagonista. Finalmente, o PSDB, que, na média do período, não conseguiu situar-se além do papel de figurante, pode ser caracterizado como o partido que mais aposta na autonomia de suas lideranças nacionais. Em quatro das campanhas ocorridas no período, atuou como figurante e, apenas em 1989 e em 2002, verificou-se uma presença mais substantiva do partido, em ambas atuando como coadjuvante. Nos pleitos mais recentes, o PSDB chegou ao ponto de adotar um discurso anti. partido, ignorando a importância da existência de um sistema partidário sólido como salvaguarda à democracia (DALTON, MCALLISTER \& WATTEMBERG, 2009). A mediação exercida pelos partidos entre elites e cidadãos é fundamental a fim de desconectar a relação direta entre demandas e resultados. Os fracassos dos partidos no exercício dessa mediação serão percebidos como fracasso do próprio sistema político. Logo, a sustentação do regime democrático "will be based on support for the parties and trust of the party elites" (DESCHOWER, 1996, p. 268).

\footnotetext{
* Protagonista (1.51 - 2.0), Semi-Protagonista (1.1 - 1.5), Coadjuvante (0.51 -1.0), Figurante (até 0.5), Apartidário (0).
} 


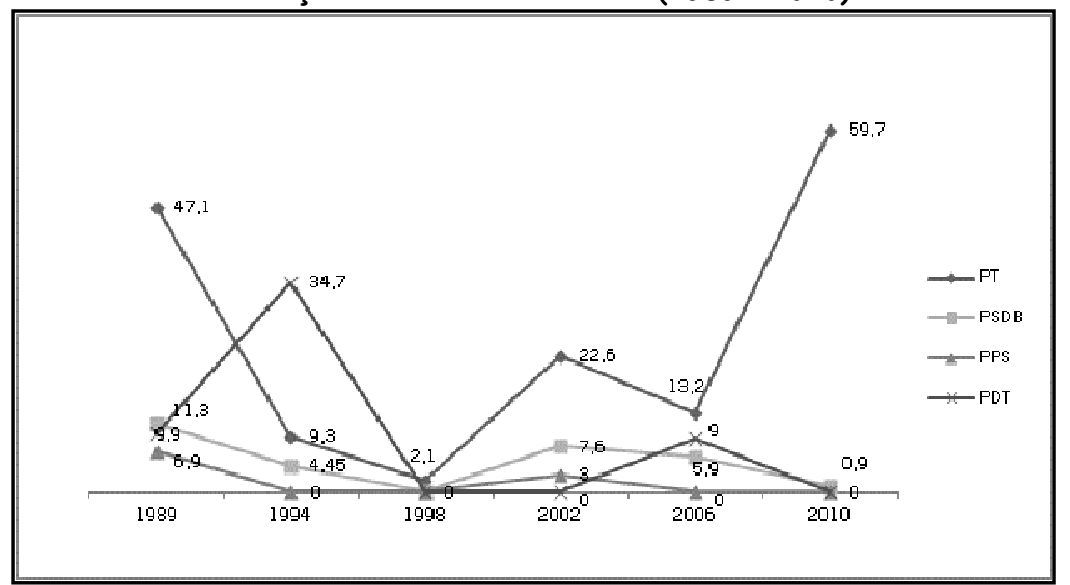

Fonte: Núcleo de Estudos Sobre Poder Partidos e Eleições (NEPPE) do Centro Brasileiro de Pesquisas em Democracia (CBPD) - PUCRS.

O Gráfico 4 apresenta a incidência do discurso partidário na propaganda, sua representatividade no conjunto da projeção da imagem partidária durante o HGPE. Isso significa dizer que, em 1989, o discurso sobre o partido respondia por cerca de $47 \%$ da imagem partidária do PT em sua campanha; cerca de $53 \%$ correspondiam a signos partidários imagéticos ou secundários. Este percentual sofreu intensa variação ao longo do período, mas finalizou em quase 60\% na campanha de 2010. Tal fenômeno explica-se, sobretudo, pelas referências ao Presidente Lula como principal liderança partidária e ao governo que estava terminando. O ano de 1998 foi o que apresentou a menor incidência de discurso partidário, para todos os partidos, pela mesma razão anteriormente apontada: a centralidade da questão da estabilidade econômica. Em contrapartida, o PSDB registrou, em 2010, sua menor ocorrência de discurso partidário em campanha, coerente com o discurso anti-partido que assumiu.

\section{Gráfico 5}

Evolução do Discurso Partidário (Média do Período 1989-2010)

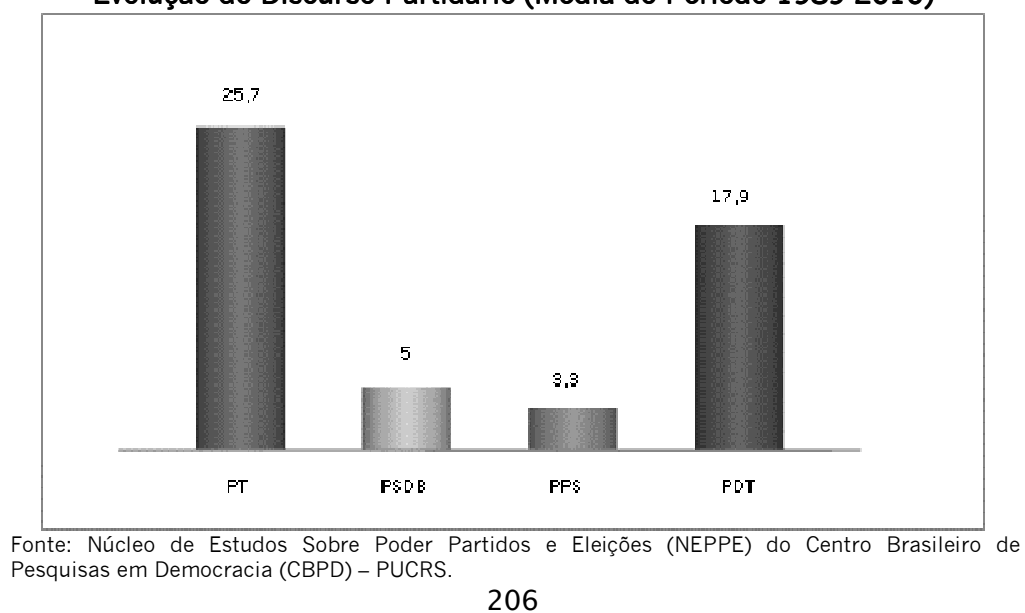


DIAS, M.R. Nas brumas do HGPE: a imagem partidária nas campanhas presidenciais...

Se analisamos o padrão médio do período, PT e PDT destacam-se pelo uso do discurso partidário. Durante as campanhas do PT, foi possível observar que, em média, em 1/4 de seu tempo na televisão, registraram-se referências verbais ao partido, direta ou indiretamente. Nas campanhas do PDT, o padrão médio de referências verbais ao partido ficou em torno de $18 \%$. PSDB (5\%) e PPS (3,3\%) não investiram significativamente nesse tipo de discurso. Importa ressaltar que o PPS é outro partido que vem adotando um discurso antipartidário. As referências partidárias nas campanhas televisivas destes dois partidos são essencialmente imagéticas, muitas delas tênues, inexpressivas, algumas quase imperceptíveis.

Finalmente, classificamos a projeção da imagem partidária na propaganda eleitoral na televisão brasileira em três categorias: imagem intensa, quando o partido destaca-se como personagem central; imagem difusa, quando a presença do partido aparece acompanhada dos partidos da coligação de apoio à candidatura; e referências indiretas, quando a identificação do partido depende da dedução do eleitor, requerendo maior conhecimento da dinâmica partidária (Gráfico 6). Mais uma vez, PT e PDT destacam. se na projeção intensa de suas imagens, enquanto PPS e PSDB utilizam significativamente uma imagem difusa ou referências indiretas a si mesmos. O PSDB foi o único partido cuja imagem difusa predominou sobre a intensa, o que o caracterizou como o partido de expressão nacional mais personalista da dinâmica eleitoral brasileira.

\section{Gráfico 6 \\ Tipo de Imagem Partidária (1989 a 2010)}

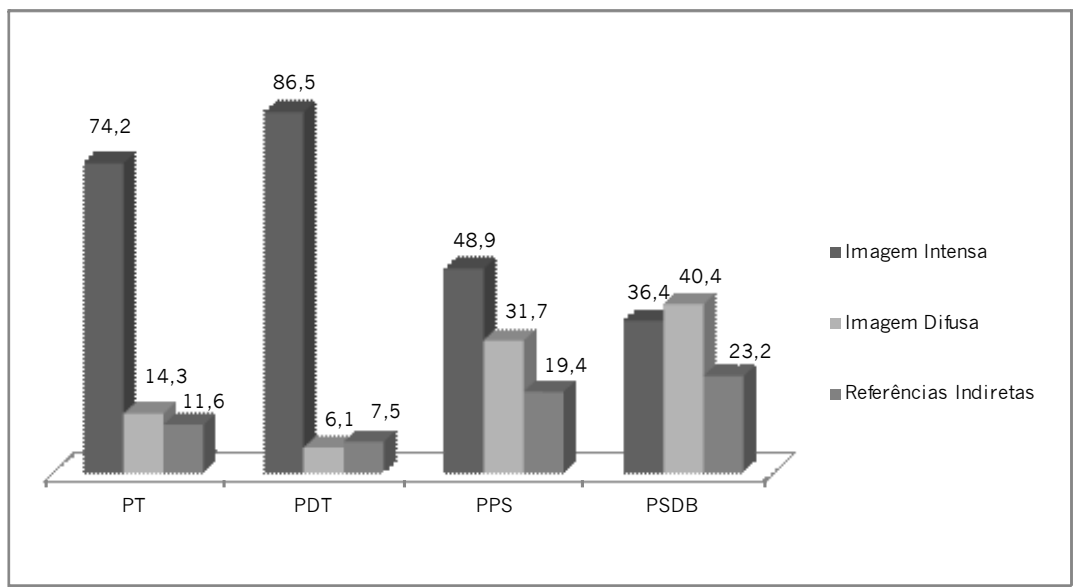

Fonte: Núcleo de Estudos Sobre Poder Partidos e Eleições (NEPPE) do Centro Brasileiro de Pesquisas em Democracia (CBPD) - PUCRS.

\section{O discurso antipartidário na campanha do PSDB}

Durante os anos 1990, a literatura acadêmica sobre os partidos políticos foi marcada pela discussão sobre a sua crise ou declínio nas democracias ocidentais contemporâneas. Parte desta literatura voltou-se à investigação do sentimento antipartidário, originado tanto nas elites políticas quanto na opinião pública. Tal sentimento teria como mote a ideia de que os partidos seriam demasiadamente autointeressados, tenderiam ao conflito político em detrimento da busca pelo bem 
comum; seriam incapazes de formular políticas públicas coerentes além de serem propensos à corrupção (POGUNTKE, 1996).

Poguntke chamou atenção para o fato de que "any attempt to arrive at a better understanding of anti-party orientations must therefore focus on the interrelationships of elite discourse and mass opinion" (POGUNTKE, 1996, p. 320). Ao enfatizarem argumentos antipartidários, as elites alimentam o ressentimento popular contra os partidos políticos, ao passo que o sucesso eleitoral de tais argumentos leva as elites a manifestá-los de forma ainda mais explícita (POGUNTKE \& SCARROW, 1996).

A campanha presidencial do PSDB em 2010 empenhou-se em consolidar argumentos antipartidários na tentativa de alimentar o sentimento contra o PT, partido do governo e principal adversário. Os três discursos a seguir traduzem a essência do sentimento descrito anteriormente:

A ideia de conflito político em detrimento do bem comum: "É por isso que nós precisamos de um governo de união, um governo de paz. É preciso parar com esse negócio do partido A ser inimigo mortal do partido $B$, de colocar uma região contra outra, irmãos contra irmãos. O Brasil é muito maior do que isso." (23/10/2010, noite; 24/10/2010, noite)

Partidos corruptos e autointeressados: "O Presidente não pode andar em más companhias, dar maus exemplos; não pode deixar roubar na sala ao lado; não pode deixar que as estatais sejam usadas pelo Partido. Hoje, o que acontece? Tem um monte de Ministério que só serve mesmo de cabide de emprego, para a turma deles. E é você quem paga o salário dessa turma toda." (25/10/2010, noite; 27/10/2010, tarde)

Partidos ineptos e autointeressados: "O país com que eu sonho é um país onde o melhor caminho para o sucesso, para a prosperidade, será a matrícula numa boa escola pública e não a carteirinha de um partido político." (21/09/2010, tarde e noite; 23/09/2010, tarde; 28/09/2010 noite; 20/10/2010, noite; 22/10/2010 tarde e noite)

Segundo Webb (1996), dois fatores são decisivos na propagação do sentimento antipartidário em um eleitorado: o desemprego e o declínio da economia nacional. $O$ autor também aponta outro fator que contribui intensamente para a hostilidade ou indiferença aos partidos, a não identificação de diferenças substantivas entre os dois maiores partidos em disputa. Nenhum desses fatores esteve presente na disputa eleitoral de 2010. 0 aumento real no número de empregos formais e a percepção de crescimento econômico, consagrada pela classificação do Brasil como oitava economia mundial foram, provavelmente, fortes obstáculos ao discurso anti-partido identificado na campanha do PSDB, principal adversário da candidatura governista. Além disso, outro argumento do PSDB que poderia ter contribuído para o sentimento anti-partido no eleitorado, o de que o governo do PT seria mera continuidade do governo do PSDB e que não se verificaria diferença significativa no modelo administrativo dos dois, perdeu sua eficácia diante da comparação entre seus resultados socioeconômicos.

Poguntke e Scarrow (1996) lembram que a questão do sentimento antipartidário pode ser investigada em duas dimensões que se influenciam mutuamente: a das elites e a das massas. Neste artigo, interessa-nos o comportamento das elites na construção da imagem partidária durante a campanha eleitoral. Poguntke e Scarrow observam que as críticas traçadas pelas elites aos partidos 
DIAS, M.R. Nas brumas do HGPE: a imagem partidária nas campanhas presidenciais...

políticos podem ser de ordem prática ou teórica. No primeiro caso, trata-se de críticas ao papel dos partidos como instituições democráticas. No segundo caso, as críticas podem assumir a linguagem de determinadas correntes da teoria democrática, como a Rousseauniana, por exemplo. Nesta perspectiva,

“(...) the expectation is that politicians' actions should directly be guided by their awareness of the common good; this expectation inevitably leads to a negative evaluation of the role of political parties as distorting intermediaries between politicians and the general will" (POGUNTKE \& SCARROW, 1996, p. 258).

A campanha do PSDB na televisão revelou este tipo de perspectiva, se considerarmos, por exemplo, o seguinte discurso do candidato Serra:

"E vou usar a minha autonomia, o meu peso político, pra fazer um governo que enfrente as
dificuldades e os grandes interesses contrariados e que não seja refém de partidos
políticos, desta ou daquela turma." (José Serra, 30/09/2010, tarde e noite)

O argumento que aqui se apresenta é o de que a autonomia do candidato e seu "peso político" são capazes de fazer mais pelo bem comum do que a política partidária, aqui vista com desprezo e tratada com desdém. A expressão: "refém de partidos políticos" é extremamente depreciativa: quem faz reféns são sequestradores, criminosos que se apoderam de pessoas, ameaçando suas vidas, a fim de que se realizem certas exigências, por exemplo, em troca de dinheiro ou poder. Outra expressão marcante nesta fala é a comparação dos partidos com "turmas", ou seja, grupos de pessoas que perseguem objetivos em comum, sejam lícitos ou ilícitos, e não instituições políticas. O objetivo é criar um imaginário, simultaneamente, ameaçador e desprezível do papel dos partidos nos governos democráticos.

Um discurso que se tornou paradigmático da campanha anti-partido do PSDB em 2010 é o que se vê transcrito a seguir:

"Eu construí meu caminho com trabalho e com esforço. Em todos os cargos que ocupei sempre trabalhei somando esforços, unindo as pessoas de bem. Nunca tratei as pessoas porque são do partido A ou do partido B. E é isso que precisa acabar no Brasil. Nós precisamos de união. Nós temos um povo trabalhador, uma terra generosa e um país grande demais pra se pensar pequeno." (José Serra, PSDB, 08/10/2010, tarde e noite; 09/10/2010, tarde)

Este pequeno discurso da campanha contém a essência da base intelectual do antipartidarismo de direita. Segundo Ignazi, a essência do problema do sentimento antipartidário está na crença em um todo harmônico, na unidade como um bem em si. "God is one. The church is one. The sovereign is one" (IGNAZI, 1996, p. 279). Na defesa da ideia de unidade e harmonia como condições para alcançar o bem comum, o PSDB usou à exaustão a imagem propositiva de um governo "acima dos partidos", como é possível notar nos exemplos a seguir: 
"E em nome dessa nova economia verde, eu digo: vamos fazer um governo das pessoas de bem, governo de união, acima dos partidos, a favor do Brasil". (José Serra, 10/10/2010, noite; 11/10/2010, tarde)

"E esse novo Brasil que nasce agora espera que seu novo Presidente faça um governo de união, acima dos partidos. E que ele tenha o tamanho da nossa Pátria, mãe gentil, Pátria amada, Brasil." (José Serra, 15/10/2010, tarde)

"Mas, eu sinto que há uma esperança: a de que nós podemos, sim, enfrentar nossos problemas como na saúde, na educação, na segurança, enfim, os grandes problemas do Brasil, sem brigas, na paz, com trabalho sério e um governo acima dos partidos". (José Serra, 10/10/2010 noite; 11/10/2010, tarde; 28/10/2010, noite)

"Sabem de uma coisa? O grande desafio do próximo Presidente é a educação. Por quê? Porque é o futuro das nossas crianças e, portanto, o futuro do Brasil. Por isso, propus fazer um pacto nacional pela educação; acima dos partidos e das disputas políticas. Durante 10 anos, no mínimo, educação não seria assunto para disputa política, muito menos eleitoral. Nós precisamos unir o Brasil para avançar na qualidade de ensino e na preparação das nossas crianças, dos nossos jovens. Esse é o nosso caminho." (José Serra, 28/10/2010, noite)

"Pra ser Presidente do Brasil tem que ter liderança, tem que estar acima dos partidos, tem que conduzir a nação. E aí, querido, para isso, nós só temos uma pessoa: Serra, 45. Para que o Brasil continue a avançar, Serra, 45." (Pastor Silas Malafaia, 16/10/2010, noite; 17/10/2010, tarde e noite)

"Quem é que tem liderança, que está acima dos partidos políticos, que está preparado, que tem experiência? Serra, 45. Pra Presidente, Serra, 45. Deus abençoe o Brasil. Deus abençoe você." (Pastor Silas Malafaia, 20/10/2010, noite; 21/10/2010, tarde)

Também segundo Ignazi (1996), em uma das vertentes do discurso anti-partido, encontra-se a hostilidade a qualquer forma de ideologia ou conflito político, fundando sua noção de política meramente na "boa gestão". Esta seria uma reação à intensa politização ocorrida no período que sucedeu a Segunda Guerra Mundial; uma ideia de pacificação dos humores políticos: um retorno ao "peace and quiet".

A campanha à Presidência do PSDB em 2010, constantemente, afirmou a superioridade intelectual, capacidade e experiência de seu candidato com relação aos adversários: "Serra é o mais preparado" foi o jargão síntese. Sua biografia política e as políticas públicas implementadas ao longo de sua carreira foram apresentadas como credenciais inquestionáveis e indispensáveis para o sucesso governamental. Somado ao discurso antipartidário, aqui amplamente demonstrado, o modelo tecnocrático de administração pública preconizado pela candidatura do PSDB colocou-se como contraponto à dinâmica político-partidária conduzida pelo governo Lula.

O destaque do PT no cenário partidário brasileiro constitui-se, simultaneamente, em sua fortaleza e fragilidade. O sentimento antipartidário está presente na sociedade brasileira e a prova disso 
DIAS, M.R. Nas brumas do HGPE: a imagem partidária nas campanhas presidenciais...

é que cerca de $40 \%$ do eleitorado votaram em uma alternativa tecnocrática. Segundo Poguntke (1996), o voto em um partido que utiliza um discurso antipartidário contém um elemento de sentimento antipartidário. A antipatia de parte do eleitorado ao PT, e aos partidos em geral, foi utilizada de forma contundente pela campanha do PSDB, especialmente na internet?

O discurso tecnocrático do PSDB, ancorando a boa governança à habilidade intelectual e qualidade técnica de suas lideranças, renegando e maculando a instituição partidária, exilando-a de seu papel de protagonista do jogo democrático, coloca em xeque sua capacidade de constituir-se em alternativa eleitoral. Como tornar efetivo um partido que fundamenta seu discurso no argumento anti. partidário? Talvez esta seja uma das razões pelas quais importantes lideranças do partido falaram, ao final das eleições de 2010, em refundação da sigla e o partido tenha encontrado em 2011 a maior crise da sua história.

\section{Lula como fiador da continuidade governamental}

Holmberg e Oscarsson (2011) demonstram que, nos sistemas políticos onde os partidos têm menor importância para o eleitorado, a influência dos líderes sobre sua decisão será maior. Nos Estados Unidos, a capacidade dos líderes de captar votos para seu partido é forte, sobretudo em eleições presidenciais. Aardal e Binder (2011) concordam e consideram que a autonomia da liderança é inversamente proporcional à solidez do sistema partidário: quanto mais frágeis os vínculos entre eleitores e partidos, mais proeminente será a posição dos líderes políticos na captação de votos para seus partidos (AARDAL \& BINDER, 2011, p. 109). Estes autores, entretanto, chamam atenção para o fato de que a literatura tem negligenciado a interveniência de distintas características partidárias no poder de influência de suas lideranças sobre o voto.

A partir de dados coletados em nove países, Aardal e Binder encontraram que o tamanho do partido é a variável mais importante do efeito da liderança no voto. O efeito da avaliação da liderança é muito maior sobre eleitores que votam em partidos grandes do que sobre aqueles que votam em partidos pequenos. 0 status governamental também estaria positivamente relacionado à capacidade de influência da liderança: o candidato que concorre à reeleição é favorecido pela maior visibilidade que possui e sua avaliação, uma vez que os resultados governamentais sejam satisfatórios, terá maior influência sobre o voto. Finalmente, a idade do partido também está positivamente associada à influência da liderança: quanto mais antigo o partido, maior será o efeito da avaliação do líder no voto que é dado ao partido. A conclusão geral dos autores é que, contrariamente a uma pressuposição amplamente difundida nos meios acadêmicos, líderes políticos não se tornaram mais importantes para os eleitores do que os partidos ou a dinâmica política: são dimensões que se relacionam e influenciam mutuamente.

O sistema partidário brasileiro tem frágil penetração no eleitorado, sendo significativa apenas a identificação partidária com o Partido dos Trabalhadores ${ }^{8}$. O PT está entre os maiores e mais antigos partidos políticos do atual sistema partidário brasileiro: criado em 1979, participou com candidato próprio em todas as eleições presidenciais ocorridas a partir de 1989, primeira eleição direta para a Presidência da República após a ditadura militar. O PT venceu a eleição presidencial com Lula em 2002

\footnotetext{
7 O conjunto de vídeos "O Brasil não é do PT", cuja autoria foi assumida pelo PSDB, é exemplo paradigmático da campanha negativa contra o PT nas eleições de 2010. Ver: <http://www.youtube.com/watch?v=V8KOaltQzQM>. Acesso em: 6 jun. 2011.

8 Sobre o assunto ver: Ames \& Power (2009).
} 
e o reelegeu em 2006. Ou seja, o caso do PT no Brasil confirma o desenho partidário ideal para a influência da liderança na captação de votos para seu partido, encontrado nas evidências analisadas por Aardal e Binder: partido grande, antigo e líder de governo.

Em 2010, vetada constitucionalmente a possibilidade de reeleição do Presidente Lula, o PT lançou Dilma Rousseff como sua candidata à Presidência. No caso desta eleição presidencial, a transferência de popularidade do Presidente Lula para sua sucessora foi notória. Lula participou intensamente da campanha de Dilma Rousseff, fazendo crer que o voto na candidata do PT era equivalente a um voto nele mesmo:

\begin{abstract}
"Daqui a dois meses eu não serei mais presidente e ficaria muito feliz em ver a companheira Dilma continuar esse trabalho, porque ela é guerreira e competente e me ajudou muito a chegar até aqui. Pela primeira vez depois de 5 eleições o meu retratinho não vai estar lá na urna. Mas na hora que você apertar o 13 e aparecer o retratinho da Dilma você vai estar votando na candidata mais preparada para ser Presidente e também vai estar votando um pouquinho em mim. Por isso, você que apoia a mim e a Dilma não deixe de votar nesse domingo. Temos que defender o que já conquistamos e garantir um futuro ainda melhor para os nossos filhos e nossos netos. Muito obrigado e uma feliz eleição." (Presidente Lula, HGPE, 29/10/2010)
\end{abstract}

Para Wattemberg (2011), a imagem pessoal da liderança não tem sido o fator determinante em eleições presidenciais, contrariando a avaliação da maioria dos analistas da chamada "candidatecentred politics". Ou seja, não são necessariamente os candidatos mais bem avaliados em termos de integridade, confiabilidade, competência e carisma que têm sido, historicamente, eleitos nos Estados Unidos:

\footnotetext{
"The key to understanding the rise of candidate-centred politics in the United States is not personality politics, but rather the increasing importance of candidate-centred issues"
} (WATTEMBeRg, 2011, p. 86).

O autor também demonstrou que o fenômeno da política centrada na liderança nos Estados Unidos pode ser classificado em dois tipos. O primeiro, mais conhecido e diagnosticado por seus pares, seria o do líder que cria uma identidade separada do seu partido. O segundo, identificado em eleições mais recentes, seria o do candidato que se torna a figura dominante em um contexto político onde o partido político é frequentemente visto pelo público através do prisma dos seus líderes. Tais líderes assim se constituem não pela força de suas personalidades, conforme o autor, mas pelo controle de uma determinada agenda política (WATEMBERG, 2011, p. 90). São, portanto, as questões da pauta pública discutidas pelos candidatos que definirão sua popularidade, e não aspectos relativos à sua personalidade.

Novamente, o caso da eleição de 2010 no Brasil confirma as análises da literatura acadêmica acerca do papel da liderança partidária em eleições democráticas recentes. O Presidente Lula tornou-se o fiador do futuro governo de Dilma, porém, não o fez em termos personalistas, mas demonstrando que sua sucessora teve papel proeminente na formulação das políticas públicas bem-sucedidas de seu 
DIAS, M.R. Nas brumas do HGPE: a imagem partidária nas campanhas presidenciais...

governo. Dilma seria a "mãe do PAC (Programa de Aceleração do Crescimento)", por exemplo. Lula compartilhou o mérito de seu governo ao vincular Dilma a um projeto político comum:

"Eu digo sem medo de errar: grande parte do sucesso do governo está na capacidade de coordenação da companheira Dilma Rousseff. Aliás, eu vou dizer, acho que não tem hoje no Brasil ninguém mais preparado do que a Dilma." (Presidente Lula, HGPE, 17/08/2010)

O objetivo estratégico era, simultaneamente, assegurar que a eleição de Dilma representaria a continuidade do governo Lula e, em virtude de sua inexperiência em cargos eletivos, demonstrar a competência da candidata como gestora. A candidata foi apresentada na propaganda do PT como principal membro da equipe de governo de Lula e a responsável pela implementação de várias de suas principais políticas públicas:

"Dilma se torna o braço direito de Lula e a primeira mulher da nossa história a ser Ministra de Minas e Energia, depois Ministra Chefe da Casa Civil. Ela coordena todo o Ministério e Programas como o 'Luz para Todos', 'PAC' e o 'Minha Casa, Minha Vida', que melhoram a vida de milhões de brasileiros e criam novas perspectivas para o país." (Narrador em "Off“" sobre imagens de Lula e Dilma em ações governamentais, 17/08/2010)

Nesse sentido, Lula atuou na campanha eleitoral de Dilma Rousseff como a própria instituição partidária, executando a mesma função. Em outras palavras, seguindo a análise de Wattemberg, o PT passou a ser visto pelo prisma de sua principal liderança: o Presidente da República. O compromisso que Lula assumiu com o eleitor ao recomendar a candidatura de sua companheira de partido não foi de caráter pessoal, de amizade ou trajetória política: Lula conheceu Dilma em 2003 e disse isso na campanha. O compromisso de ambos com o eleitorado deu-se em termos de agenda política: governaram juntos e ela era capaz de continuar sem ele. Desta forma, a participação do Presidente Lula na campanha de Dilma foi mais do que a transferência de prestígio pessoal, mas, sobretudo, a afirmação de um projeto político comum, isto é, de uma agenda político-partidária:

"Tenho muito orgulho de ter começado esse trabalho e a maior certeza do mundo de que a Dilma vai dar os passos que ainda faltam para o Brasil se transformar em um país realmente desenvolvido". (Presidente Lula, HGPE, 28/09/2010)

O Presidente Lula executou outras funções partidárias durante a campanha, como por exemplo, blindar a candidata, defendendo-a de ataques e acusando adversários de estarem fazendo uma campanha desleal. Como Lula não concorria naquela eleição, ele pôde atacar o principal adversário do seu partido, preservando a candidata Dilma do desgaste que a campanha negativa poderia ter causado em sua imagem pessoal:

"Você sabe que nossa candidata Dilma tem feito uma campanha elevada, discutindo propostas e ideias, mostrando o que fizemos e o que ainda vamos fazer pelo Brasil. Mas, infelizmente, nosso adversário, candidato da turma do contra, que torce o nariz pra tudo o que o povo brasileiro conquistou nos últimos anos, resolveu partir para os ataques pessoais e para a baixaria." (Presidente Lula, Programa eleitoral PT, 07 de setembro de 2010) 
Mais uma vez, o Presidente Lula atuou como fiador de sua sucessora, ou seja, como o próprio partido. Ele afirma que a campanha de sua candidata é propositiva e positiva, enquanto seu adversário teria uma postura negativa, antipática aos resultados do governo e antipolítica, na medida em que dedicava-se a "ataques pessoais". O que Lula faz é a crítica da crítica, posição mais facilmente assumida por partidos governistas do que oposicionistas, um dos aspectos que colocam a campanha dos primeiros em vantagem comparativa a dos segundos. Em estudo recente, Aarts e Blais (2011, p. 179) afirmam que as avaliações positivas têm um impacto maior na decisão eleitoral do que as avaliações negativas, afirmando a existência de um viés de positividade na decisão eleitoral e rejeitando a hipótese da negatividade:

"There is no evidence that negative advertising or campaigning is more effective than positive advertising and/or that voters punish governments for bad economic times but do not reward them for good times" (AARTS \& BLAIS, 2011, p. 180).

O caso da eleição de Dilma Rousseff em 2010 para a Presidência do Brasil confirma os resultados encontrados por Aarts e Blais. Por um lado, a campanha negativa do PSDB não foi capaz de credenciar seu candidato à vitória, por outro, os resultados socioeconômicos do governo Lula favoreceram a candidatura de sua sucessora, que, até então, era desconhecida do eleitorado e nunca havia passado pelo teste das urnas. A vitória da candidata do PT refletiu a aprovação do governo Lula junto à maioria do eleitorado. A ideia de governo compartilhado entre o Presidente e sua sucessora foi uma estratégia partidária e eficaz. Partidária, na medida em que dava garantias de que a continuidade governamental independia da liderança de Lula; as políticas implementadas eram um projeto político comum, uma agenda mediada pelo partido, embora este quase nunca fosse mencionado. Eficaz porque convenceu a maioria do eleitorado que aprovava a referida agenda a votar na candidatura de Dilma.

\section{Conclusão}

Este artigo teve como propósito elaborar um diagnóstico da imagem partidária na propaganda eleitoral na televisão durante as campanhas presidenciais brasileiras, a partir da redemocratização dos anos 1980. Procuramos identificar a intensidade da visibilidade partidária, tanto visual quanto discursiva, a fim de classificar a relevância do papel de cada partido em seu "próprio espetáculo", já que o HGPE é distribuído partidariamente, segundo o tamanho de cada bancada parlamentar.

Na primeira parte do artigo, foi destacada a irrelevância da imagem partidária nas campanhas presidenciais de todos os partidos concorrentes. Este é o sintoma mais evidente da crescente profissionalização das campanhas presidenciais no Brasil, que possui como consequência, segundo a literatura especializada, o enfraquecimento do papel que os partidos exercem nas campanhas de seus candidatos. Já as campanhas televisivas para cargos legislativos destacaram-se pela intensidade da presença partidária junto a seus candidatos. Tal fenômeno explica-se, em primeiro lugar, pelo próprio sistema eleitoral brasileiro que computa tanto votos dados diretamente aos candidatos quanto votos de legenda para o cálculo do coeficiente partidário. Em segundo lugar, a utilização do tempo destinado às campanhas para o legislativo na promoção da candidatura aos cargos executivos do mesmo partido também contribuiu para a alta incidência de partidarismo das referidas campanhas. 
DIAS, M.R. Nas brumas do HGPE: a imagem partidária nas campanhas presidenciais...

Em um ambiente tão diverso, a opção neste artigo foi tratar exclusivamente das campanhas presidenciais: a imagem partidária pode, portanto, ser analisada em um contexto de escassez, reduzindo a irrelevância da estratégia partidária e tornando os partidos comparáveis entre si.

Desde 1994, as eleições presidenciais no Brasil têm sido polarizadas entre dois partidos, os únicos que participaram das seis eleições ocorridas no período analisado: PT e PSDB. Entre 1989 e 1998, o PT ficou em segundo lugar nas disputas; entre 2002 e 2010, o PSDB terminou em segundo lugar. À exceção de 1989, as demais eleições foram ganhas por esses dois partidos: 1994 e 1998 pelo PSDB; 2002, 2006 e 2010 pelo PT. Dessa forma, configurou-se virtualmente um sistema bipartidário, visto que apenas dois partidos vêm apresentando vocação majoritária em âmbito nacional, o que justifica que a análise qualitativa tenha se concentrado nos mesmos.

Da análise quantitativa apreenderam-se as seguintes conclusões:

- Dos partidos analisados, apenas o PT pode ser considerado "protagonista" de sua campanha eleitoral;

- PDT e PPS, os outros dois partidos analisados por terem participado de três das seis campanhas, atuaram, em média, como "coadjuvantes";

- O PSDB atuou, em média, como "figurante" em suas campanhas, caracterizando-se como o partido que mais aposta na estratégia individualista.

Depois de contabilizadas as referências partidárias em cada campanha, tanto visuais quanto verbais, o tipo de imagem que cada partido projetou - intensa, difusa ou indireta - foi analisada. $\mathrm{Na}$ imagem partidária projetada nas campanhas do PT e do PDT, predominou o tipo intenso ou explícito; nas campanhas do PPS e do PSDB não foi possível perceber o predomínio de nenhum dos tipos de imagem, entretanto, foi registrado o uso significativo das imagens difusa e indireta. O PSDB foi o único partido cuja imagem difusa foi mais frequentemente utilizada do que a imagem intensa, acentuando seu perfil personalista.

Em 2010, o perfil individualista das campanhas presidenciais do PSDB ganhou contornos ainda mais acentuados na adoção explícita do argumento antipartidário. Tal argumento já vinha se delineando desde 1994, quando o PSDB articulou aliança com o Partido da Frente Liberal (PFL), atual Democratas (DEM), e venceu a eleição presidencial com Fernando Henrique Cardoso. Já nessa época, a ideia da supremacia do interesse nacional sobre interesses setoriais estava presente na campanha, justificando a aliança entre a social-democracia e o liberalismo, mas foi em 2006 que tal argumento começou a se transformar em sentimento anti-partido. A razão para a intensificação do argumento tecnocrático. individualista e para a rejeição à instituição partidária na campanha do PSDB tem uma evidente razão política: enfraquecer o adversário pelo que melhor o caracteriza, organização e disciplina partidárias. Como vimos no decorrer do artigo, o PT é o partido brasileiro mais consistente, tanto em vínculos com o eleitorado quanto em controle sobre suas elites, o que se confirma por sua participação direta nas campanhas.

O governo que terminava em 2010 sob o comando do Presidente Lula apresentava elevados índices de aprovação. O crescimento da economia, o aumento do número de empregos formais e o sucesso dos programas sociais do governo impossibilitaram a construção de uma campanha oposicionista com base em argumentos retrospectivos. Neste cenário, a campanha do PSDB investiu no 
prestígio do seu candidato, no argumento da superioridade moral e da capacidade individual para construir a unidade e articular o bem comum em substituição à política partidária, apresentada como algo desprezível e ameaçador.

O que mais se destacou na campanha presidencial do PT em 2010 foi a intensa participação do Presidente Lula na defesa da candidatura daquela que seria sua sucessora. Sua influência na escolha do eleitor é considerada por muitos analistas peça-chave no sucesso da campanha do PT. Neste artigo, procurei analisar a natureza da participação de Lula na campanha e concluí que, contrariamente à lógica do senso comum, isso não significou a decadência do Partido dos Trabalhadores ou sua fragilidade na campanha, mas, ao contrário, confirmou o sucesso eleitoral da estratégia partidária. Lula encarnou o PT ao dizer que o voto em Dilma Rousseff era equivalente ao voto nele mesmo, uma vez que eles eram parceiros em um mesmo projeto político, não declaradamente partidário em função do sentimento antipartido difundido no eleitorado, mas equivalente.

A função do partido político em qualquer democracia é reunir pessoas com uma ideologia e um projeto em comum. Ao afirmar que a participação de Dilma em seu governo foi fundamental para o sucesso obtido e que a continuidade do mesmo estaria garantida com a sua eleição, Lula favoreceu a transferência da sua popularidade - não como líder carismático, porque isso não se transfere, mas como governante - à candidata de seu partido. A estratégia adotada na campanha ao investir na imagem do Presidente Lula, portanto, não foi personalista, mas partidária, ao afirmar um projeto coletivo cujos símbolos eram a estrela, marca registrada do PT, e a cor vermelha.

A estrela vermelha é um símbolo universal de orientações político-ideológicas de esquerda, especialmente socialistas ou comunistas. É a estrela na boina de Che Guevara, símbolo universal do movimento revolucionário de esquerda, especialmente na América Latina. Não é preciso conhecimento teórico sobre o assunto: é de domínio público, pertence ao senso comum. Nesse sentido, a proeminência do símbolo partidário na campanha do PT, especialmente em 2010, é ainda mais eloquente do que sua própria sigla e sustenta um conteúdo ideológico ainda mais robusto. A estrela esteve presente em 54\% das peças analisadas da campanha do PT de 2010. Apenas em termos comparativos, o tucano, símbolo do PSDB, estrela da campanha de 1989 (presente em um terço das peças analisadas), apareceu apenas duas vezes na campanha presidencial de 2010. Isso mostra que o PT não teve sua identidade fragilizada pela "moderada" experiência governamental. A estrela é certamente uma marca, porém, uma marca carregada de significados.

O vermelho é a cor predominante nas bandeiras da maioria dos partidos social-democratas, nacionalistas, socialistas e comunistas. Assim como a estrela, a cor vermelha possui um significado ideológico implícito. A campanha de 2010 foi uma das mais vermelhas do período analisado. O vermelho sempre esteve presente nas campanhas através das imagens de comícios, um ponto forte do PT. Nesse ano, porém, esteve presente de forma ainda mais contundente, na medida em que foi "vestido" pela candidata. Em 100\% dos programas televisivos veiculados, Dilma Rousseff aparece pelo menos uma vez vestida de vermelho, demonstrando um compromisso pessoal da candidata com os valores de esquerda e, sobretudo, um compromisso com o PT, partido ao qual se filiou tardiamente, depois de passar pelo PDT. 
DIAS, M.R. Nas brumas do HGPE: a imagem partidária nas campanhas presidenciais...

Em sua reta final, a campanha de 2010 trocou argumentos políticos por argumentos morais, misturou política e religião ferindo o princípio de laicidade do Estado Moderno e atacou instituições indispensáveis para a democracia como são os partidos políticos. A internet, que não foi objeto de análise neste artigo, tornou-se veículo para o ataque entre candidatos: conviveram neste ambiente discussões ideológicas, acusações morais e mensagens eletrônicas difamatórias. Isso faz com que a internet torne-se progressivamente um campo profícuo para a investigação acadêmica dos processos eleitorais. Agenda indispensável para estudos futuros.

\section{Referências Bibliográficas}

AARTS, K.; BLAIS, A. Pull or Push? The Relative Impact of Positive and Negative Leader Evaluations on Vote Choice. In: AARTS, K.; Blais, A.; SCHIMITT, H. (orgs.). Political Leaders and Democratic Elections. Oxford: Oxford University Press, 2011.

Aardal, B.; Binder, T. Leader Effects and Party Characteristics. In: AArTs,K.; Blais, A.; Schimitt, H. (orgs.). Political Leaders and Democratic Elections. Oxford: Oxford University Press, 2011.

Albuquerque, A. "Política versus Televisão: O Horário Gratuito na Campanha Presidencial de 1994". Comunicação \& Política, vol. 1, n 3, p. 49.54, 1995.

. Aqui você vê a verdade na tevê - A propaganda política na televisão. Niterói: Publicações do Mestrado em Comunicação, Imagem e Informação - UFF, 1999.

Albuquerque, A.; Dias, M. R. "Propaganda Política e Construção da Imagem Partidária no Brasil". Civitas, vol. 2, n 2, p.309-326, 2002a.

"Partidos Políticos em Campanha: Notas para uma metodologia de análise da propaganda política na televisão". Anais da XVI ANPOCS, Caxambu, MG, 2002b.

Albuquerque, A.; Steibel, F. B.; Carneiro, C. M. Z. "A Outra Face do Horário Gratuito: Partidos Políticos e Eleições Proporcionais na Televisão", Dados, vol. 51, p. 459.487, 2008.

Ames, B.; Power, T. Parties and Governability in Brazil. In: WebB, P. \& White, S. (orgs.). Party Politics in New Democracies. Oxford: Oxford University Press, 2009.

CERVI, E. U. "O uso do HGPE como recurso partidário em eleições proporcionais no Brasil: um instrumento de análise de conteúdo". Opinião Pública, Campinas, vol. 17, n 1, jun. 2011.

Cervi, E. U.; Massuchin, M. G.; Tavares, C. Q. "Agenda da mídia, dos políticos e do público na campanha eleitoral de 2010". Revista Debates, Porto Alegre, vol. 6, n 1, p.237-261, jan.-abr. 2012.

Dalton, R. J.; McAllister, I.; Wattemberg, M. P. The Consequences of Partisan Dealignment. In: Dalton, R. J.; Wattenberg, M. P. (orgs.). Parties without Partisans. Political Change in Advanced Industrial Democracies. Oxford: Oxford University Press, 2009.

DesChOWER, K. "Political Parties and Democracy: a Mutual Murder?" European Journal of Political Research, vol. 29, p. 263.278, 1996.

DIAS, M. R. "Projeção da imagem partidária nas estratégias de campanha na televisão: uma análise do HGPE 2002". Dados, Rio de Janeiro, vol. 48, n 1, p. 147-183, 2005.

"Republicanismo Adjetivado: as dimensões aristocrática e democrática nos discursos da campanha presidencial brasileira de 2006". Revista Compolítica, vol. 2, n 1, jan-jun. 2012.

Figueiredo, M.; Aldé, A.; Dias, H. \& JoRge, V. L. Estratégias de Persuasão em Eleições Majoritárias: Uma Proposta Metodológica para o Estudo da Propaganda Política. In: FigueIREDo, R. (Org.). Marketing Político e Persuasão Eleitoral. São Paulo: Fundação Konrad Adenauer, 2000.

Figueiredo, R.; Coutinho, C. "A eleição de 2002". Opinião Pública, Campinas, vol. 9, n² 2, out. 2003. 
GiBSON, R.; RÖMmELE, A. "Changing Campaign Communications: a party-centered theory of professionalized campaigning". Harvard International Journal of Press Politics, vol. 6, n 4, p. 31.43, 2001.

Holmberg, S.; Oscarssom, H. Party Leaders Effects on Vote. In: Aarts, K.; Blais, A.; Schimitt, H. (orgs.). Political Leaders and Democratic Elections. Oxford: Oxford University Press, 2011.

IgnazI, P. "The Intellectual Basis of Right Wing Anti-Partyism". European Journal of Political Research, vol. 29, p. $279 \cdot 296,1996$.

KIngstone, P.; PoWer, T. Democratic Brazil Revisited. Pittsburgh: University of Pittsburgh Press, 2008.

LOURENCO, L. C. "HGPE e Intenção de voto: observações sobre as eleições de 1998 ao governo de São Paulo e à Presidência da República". In: XI Congresso dos Sociólogos do Estado de São Paulo, PUC.SP, 2001.

"Propaganda negativa: ataque versus votos nas eleições presidenciais de 2002". Opinião Pública, Campinas, vol. $15, n^{\circ} 1$, jun. 2009

McCombs, M.; SHAW, D. "The agenda-setting function of mass media". Public Opinion Quaterly, New York, vol. 36, $n^{\circ} 2$, p. 176-87, 1972.

MigueL, L. F. "Discursos cruzados: telenoticiários, HGPE e a construção da agenda eleitoral". Porto Alegre: Sociologias, ano $6, n^{\circ} 11$, p. $238 \cdot 258$, jan/jun. 2004.

Negrine, R. M.; LILlekeR, D.G. "The Professionalization of Political Communication: continuities and change in media practices". European Journal of Political Communication, vol. 17, n³ 3, p. 305-323, 2002.

Nicolau, J.; Power, T. Instituições Representativas no Brasil: Balanço e Reforma. Belo Horizonte: Editora da UFMG, 2007.

PLASSER, F. "Parties' Diminishing Relevance for Campaing Professionals". Harvard International Journal of Press Politics, vol. $6, n^{\circ} 4$, p. 44-59, 2001.

PogUnTKE, T. "Anti-Party Sentiment - Conceptual Thoughts and Empirical Evidence: Explorations into a Minefield". European Journal of Political Research, vol. 29, p. 319-344, 1996.

.; SCARRow, S. E. "The Politics of Anti-Party Sentiment: Introduction". European Journal of Political Research, vol. 29, p. 257.262, 1996.

Römmele, A. "Political Parties, Party Communication and New Information and Communication Technologies". Party Politics, vol. 9, $\mathrm{n}^{\circ} 1$, p. 7.20, 2003.

SAMUELS, D. "Determinantes do voto partidário em sistemas eleitorais centrados no candidato: evidências sobre o Brasil". Dados, Rio de Janeiro, vol. 40, 1997.

SCHIMITT, R.; CARNEIRO, L. P.; KUSCHNIR, K. "Estratégias de campanha no horário gratuito de propaganda eleitoral em eleições proporcionais". Dados, Rio de Janeiro, vol. 42, n² 2, 1999.

VEIGA, L. F. Em Busca de Razóes para o Voto: o uso que o homem comum faz do Horário Eleitoral. 2001. Rio de Janeiro, 246 f. Tese (Doutorado em Ciência Política), IUPERJ, 2001.

Wattemberg, M. P. US Party Leaders: Exploting the Meaning of Candidate-Centered Politics. In: Aarts, K.; BLAIS, A.; SchImItT, H. (orgs.). Political Leaders and Democratic Elections. Oxford: Oxford University Press, p. 76.90, 2011.

WEBB, P. D. "A partisanship and anti-party sentiment in the United Kingdom. Correlates and constraints. European Journal of Political Research, vol. 29, issue 3, 1996. 
DIAS, M.R. Nas brumas do HGPE: a imagem partidária nas campanhas presidenciais...

\section{Nota Metodológica}

O procedimento metodológico adotado para a organização dos dados quantitativos seguiu as seguintes etapas: em primeiro lugar, os dados acerca da presença partidária na propaganda eleitoral veiculada na televisão foram identificados e coletados. Em planilhas de Excel, separadas por partido, estabeleceram-se os seguintes critérios classificatórios:

\begin{tabular}{|l|l|l|l|l|}
\hline \multirow{2}{*}{ Categorias Visuais } & \multicolumn{2}{|c|}{ Estúdio } & \multicolumn{2}{c|}{ Externo } \\
\cline { 2 - 5 } & Cenário & Pessoas & Cenário & Pessoas \\
\hline Legenda do partido & & & & \\
\hline Símbolo do partido & & & & \\
\hline Nome da coligação & & & & \\
\hline Legenda da coligação & & & & \\
\hline Aparição liderança partidária & & & & \\
\hline Endereço página WEB & & & & \\
\hline Legenda do partido em bandeiras & & & & \\
\hline Símbolo do partido em bandeiras & & & & \\
\hline
\end{tabular}

\begin{tabular}{|l|l|l|l|l|l|l|}
\hline Categorias Discursivas & Populares & Locutor & Candidato & Celebridade & Liderança & Outros \\
\hline Menção explícita ao partido & & & & & & \\
\hline Menção à bandeira do partido & & & & & & \\
\hline Menção ao símbolo do partido & & & & & & \\
\hline Menção à coligação & & & & & & \\
\hline Menção à liderança partidária & & & & & & \\
\hline Menção a gestões anteriores (partido) & & & & & & \\
\hline
\end{tabular}

Cada segmento do programa eleitoral foi analisado separadamente. Um segmento, ou peça, corresponde a cada cena do programa que organiza uma mensagem, que é transmitida por um ou mais personagens. Os critérios definidos foram contabilizados apenas uma vez por peça. O Indicador de Projeção da Imagem Partidária (IPIP) foi calculado a partir do somatório de todos os critérios, dividido pelo número de segmentos apresentados por cada partido em sua propaganda. O objetivo da construção deste valor indicativo foi atenuar as disparidades que poderiam ser causadas em virtude da distribuição desigual do tempo entre as candidaturas. Assim, um partido, mesmo com poucos segundos na televisão poderia atingir o IPIP igual ou maior do que 1 , desde que a mensagem de seu programa apresentasse signos partidários visuais ou discursivos.

Marcia Ribeiro Dias-mrdias@pucrs.br

Submetido à publicação em janeiro de 2012.

Versão final aprovada em março de 2013. 